\title{
EDAPHIC MITES AND THEIR RESPONSE TO THE INCORPORATION OF ORGANIC MATTER FROM VARIOUS SPECIES OF FABACEAE INTO THE SOIL BENEATH COFFEE TREES
}

\author{
Thialgo A.F. Carvalho', Paulo R. Reis ${ }^{2}$, Leopoldo F.O. Bernardi ${ }^{3^{*}}$, \\ Patricia P. Marafeli ${ }^{1}$ and Pablo A. Martinez ${ }^{4}$
}

\author{
${ }^{1}$ Federal University of Lavras, Department of Entomology, Lavras, Brazil \\ ${ }^{2}$ Agriculture and Livestock Research Enterprise of Minas Gerais, EPAMIG Sul/EcoCentro, \\ Vicosa, Brazil \\ ${ }^{3}$ Federal University of Lavras, Department of Biology, Ecology Sector, Lavras, Brazil \\ ${ }^{4}$ Federal University of Sergipe, Faculty of Exact and Natural Sciences, Department of Biology, \\ Argentina \\ *corresponding author; e-mail: leopoldobernardi@gmail.com.br
}

\begin{abstract}
The aim of this study was to evaluate the presence and abundance of mites in the soil beneath cultivated coffee trees (Coffea arabica L.). In particular, we compared mite communities in three different soil environments: 1) native forest; 2) soils from underneath the coffee trees "under full sun" (i.e. areas that received no additional shade or organic treatment); 3 ) soils that incorporated organic matter from four leguminous windbreak plant species - acacia, Acacia mangium Wild.; pigeon pea, Cajanus cajan (L.) Millsp.; gliricidia, Gliricidia sepium (Jacq.) Walp.; and leucaena, Leucaena leucocephala (Lam.) de Wit. Sampling was conducted at the ends of the dry and rainy seasons, in São Sebastião do Paraíso, Minas Gerais, Brazil. Undisturbed soil samples were acquired using a cylinder and a Berlese-Tullgren funnel was used to extract the mites in the laboratory. A total of 1,014 mite specimens, assigned into 143 different species, were collected. The forest soil had the greatest richness and total abundance of edaphic mites, while the coffee plantation soils, enriched with acacia, had the lowest richness and abundance. The mite communities of treated soils were less than $18 \%$ similar to that of the forest soil. These results suggest that the substitution of native forests with cultivated systems can cause significant changes in the abundance, richness and structuring of edaphic mite communities, particularly of oribatid mites. Maintenance of mite communities should be one of the goals of agricultural practices, since these organisms are important for maintenance of biological cycles, especially for the decomposition of organic matter.
\end{abstract}

KEY WORDS: Acarology, edaphic mites, mesofauna, Coffea arabica.

DOI: 10.21684/0132-8077-2018-26-2-183-195

\section{INTRODUCTION}

Efforts have been made with several agricultural crops to implement responsible crop cultivation practices. Namely, researchers have been trying to come up with management systems that are minimally invasive to the diverse fauna and flora of such areas (Perfecto et al. 1996; Moguel and Toledo 1999). The search for such sustainable cultivation models has been the focus of studies of coffee growing practices (Perfecto et al. 1996; Moguel and Toledo 1999).

Based on the concept of sustainable production, the research, focused on soil-plant interaction, has abandoned the idea that soil fertility is solely the result of its intrinsic chemical and physical properties (Oliveira et al. 2006). Thus, a fertile soil that is suitable for cultivation, should not only be rich in nutrients and free from physical processes that impede crop implementation-such soil should also be biologically active, so that nutrient cycling processes may be completed (Oliveira et al. 2006).

The biological community of soil consists of numerous organisms including plants, lichens, bacteria, fungi and a wide range of arthropods, which are responsible for several activities that directly and indirectly influence the chemical and physical properties of the soil (Pankhurst and Linch 1994, Theenhaus and Scheu 1996). In addition, these organisms may play a role in soil regeneration, thereby benefiting vegetation by making nutrients available and maintaining equilibrium among the populations of organisms present (Uhlig 2005).

Mites are an important component of the edaphic fauna, and they may represent as many as 95\% of all microarthropods in the soil (Seastedt 1984). Edaphic mites are characterized by a vast diversity of species and feeding habits. They can be strictly predatory, or they can feed on microorganisms and decomposing matter; their feeding habits may also vary throughout their life cycle, e.g., parasitic immatures transforming to predacious adults. Among predatory mites, there are those that feed on nematodes, larvae and adults of other invertebrates, including mites (Evans and Campbell 2003; Castilho et al. 2009; Moreira et al. 2015). Given this variation in feeding habits, 
T.A.F. Carvalho, P.R. Reis, L.F.O. Bernardi et al.

some predatory species have been widely used in agriculture. Others, namely the species of the families Macrochelidae, Laelapidae and Rhodacaridae, may be used as biological control agents for the soil (Wallace et al. 1979; Evans and Campbell 2003; Castilho et al. 2009; Moreira et al. 2015).

Since mites live in soil, they may serve as indicators of soil quality (Rieff 2010). Therefore, the collection of certain edaphic organisms and the analysis of their population parameters (e.g., richness, abundance, exclusive species and quality indicator species) permits the evaluation of soil quality in cultivated areas and natural environments (Ruf 1998; Ruf and Beck 2005; Bedano and Ruf 2010). Such information can contribute to the maintenance, recovery and restoration of the environmental health, and thus, to the sustainability of ecosystems (Ruf 1998; Ruf and Beck 2005; Bedano and Ruf 2010).

Although the greatest richness of edaphic mites is found in native forests, several species of this group can be found in other systems, including anthropic environs. However, even in situations characterized by lower abundances and fewer species, mites may perform important biological functions, such as pest control and nutrient cycling (Crossley et al. 1992; Hülsmann and Wolters 1998; Bedano et al. 2006; Morais et al. 2010). The same occurs in coffee cultivation areas, where the substitution of native vegetation tends to negatively affect soil acarofauna, with the reduction in the richness and abundance of soil species (Rojas et al. 2009; Marafeli et al. 2018). However, coffee cultivation with a shading system may reduce the loss of biodiversity. This type of management, which maintains part of the native vegetation integrated into the cultivation system, allows the maintenance of a greater species richness than conventional types of agricultural practices (Perfecto et al. 1996; Moguel and Toledo 1999). Thus, one of the issues that must be considered is how to reconcile agricultural production and expansion with practices that are less detrimental to biodiversity. The objective of the present study was to evaluate the occurrence and variation in the edaphic mite fauna that occurs in the soil beneath coffee trees with and without the incorporation of organic matter into the soil. The present study compared three environments: coffee crops grown in the shade produced by rows of arboreal Fabaceae; coffee grown in full sun; and native forest.

\section{MATERIAL AND METHODS}

\section{Mite community sampling}

The present study was conducted at the EPAMIG Sul Experimental Farm in São Sebastião do Paraíso, in the state of Minas Gerais, Brazil $\left(20^{\circ} 54^{\prime} 37.32^{\prime \prime} \mathrm{S} ; 47^{\circ} 06^{\prime} 43.8^{\prime \prime} \mathrm{W}\right)$. The site is $837 \mathrm{~m}$ a.s.l. The region has a mean annual temperature of $20.8{ }^{\circ} \mathrm{C}$ and a mean annual rainfall of approximately $1,400 \mathrm{~mm}$. The rains mainly occur between October and April. The soil of the region is the Dystroferric Red Latosol.

The experiment was conducted in an open area of a conventional coffee plantation without any control of the environmental factors. As a reference farm for research activities, numerous experiments regarding coffee management are conducted in the area. These research activities are conducted with the aim of better understanding the dynamics of coffee growing areas. Nonetheless, during the present experiment, no other activities were conducted that could have interfered with the results.

At the site, there was only Topázio (Coffea arabica L.), which was planted in December 1999. The coffee plant rows were spaced $3.5 \mathrm{~m}$ apart, with $0.5 \mathrm{~m}$ between plants in a given row. The total plant density was approximately 5,714 plants/ ha. Interlaced with every five rows of coffee plants, trees of Fabaceae family were planted perpendicular to the prevailing winds to serve as windbreaks. The plantation is managed in a conventional manner, as is recommended for cultivating arabic type coffee, including annual fertilization. One aspect, in which the farm deviates from the convention, has to do with using legume plant matter as windbreaks. This incorporation of vegetal organic matter from leguminous plants is the central focus of the present study. Weeding of grasses and growing between the rows of coffee is performed manually and only when this undergrowth exceeds approximately $20 \mathrm{~cm}$.

The forest area located next to the coffee plantation (less than $1 \mathrm{~km}$ away) was used as a control area. This forest is in the state of secondary succession; it has been left untouched and unmanaged since 1972, when the farm was acquired by EPAMIG Sul.

To evaluate whether the organic matter from Fabaceae plants influences the edaphic mite community, the soils from the areas, shaded by these plants, were evaluated. The incorporation of organic matter occurs when the Fabaceae plants are 
annually thinned, and their branches, leaves and fruits fall beneath the coffee trees, thus coming into contact with the soil. This practice is common in organic coffee plantations and has the objective of enriching the soil by nutrients (e.g., nitrogen) and organic matter, derived from the decomposition of Fabaceae vegetal pieces (Ricci 2005).

Four species of Fabaceae were used to enrich the soil in the experimental area: acacia, Acacia mangium Wild.; pigeon pea, Cajanus cajan (L.) Millsp.; gliricidia, Gliricidia sepium (Jacq.) Walp.; and leucaena, Leucaena leucocephala (Lam.) de Wit. Each of them was incorporated into their respective coffee tree row. As previously mentioned, some rows received no shade and no organic matter from the Fabaceae plants (i.e. full sun).

Soil sampling was conducted during two collection events: one during the end of the dry season (5 November 2012) and another at the end of the rainy season (15 April 2013). In each season, soil samples were taken as follows. Four samples were taken from the areas where four different types of Fabaceae plants were incorporated into the soil. In addition, a sample was taken from within a coffee area without the incorporation of organic matter. Finally, a sample was taken from within an area of forest with native vegetation. Thus, the samples encompassed a total of six areas, each of them was sub-sampled four times in the dry season and four times in the rainy season. The soil samples taken from the different systems were spaced four meters from each other. Soil samples taken during the rainy season were obtained near the same spots that were used during the dry season; samples taken during both seasons were subsequently combined into one. Soil sampling was accomplished with a stainless-steel cylinder probe $(50 \mathrm{~mm}$ internal diameter, height of $53 \mathrm{~mm}$; $100 \mathrm{~cm}^{3}$ ) for the collection of undisturbed soil samples (BRAVIFER - Indústria de Equipamentos e Assessoria Agronômica Ltda, ME).

Edaphic organisms were extracted in the laboratory using a Berlese-Tullgren extracting funnel (Walter and Krantz 2009; Camargo et al. 2015). The samples were extracted into collecting flasks with $70 \%$ alcohol, using light and heat for seven days.

After extraction, mites were mounted on glass slides in a Hoyer's medium, counted with the assistance of a binocular stereomicroscope and identified with the use of a phase-contrast binocular microscope.

Mite sampling extraction and identification were conducted in the Laboratory of Agricultural Acarology EPAMIG Sul/Research Center, in Eco- logical Management of Pests and Plant DiseasesEcoCenter, in the city of Lavras, Brazil.

The mites were identified to the order and family levels following Krantz and Walter (2009), with the elevation of suborder Endeostigmata to order, as suggested by Pepato and Klimov (2015). In addition, to better visualize the results, the order Sarcoptiformes was split into the Cohort Astigmatina and the remaining Oribatida.

After the initial separation into orders and families, specimens were identified to the most specific taxonomic level possible. When species identification was not possible, the mites were separated into morphospecies to facilitate statistical analysis. Whenever possible, species identification and separation into morphological types (recognizable taxonomic units) was accomplished with the aid of specialists on various groups of mites.

Voucher specimens for the species and morphospecies of mites were deposited into the following collections: the acarological collection of the Laboratory of Agricultural Acarology EPAMIG Sul (Lavras, Brazil); the Museo Nacional de Ciencias Naturales Bernardino Rivadavia (Buenos Aires, Argentina) - voucher specimens of Oribatida; the mite reference collection of Escola $\mathrm{Su}-$ perior de Agricultura "Luiz de Queiroz", (Piracicaba, Brazil) - voucher specimens of Acaridae and Mesostigamata; and the Museu de Ciências Naturais (ZAUMCN), UNIVATES-Centro Universitário (Lajeado, Brazil)—voucher specimens of Cunaxidae.

\section{Data analysis}

Mean species richness (number of species found) and mean total abundance were calculated for each sampling area. Generalized linear models (GLM) with contrast analysis were used to determine if there were significant differences in edaphic mite richness and abundance among the six sampled areas (native forest; coffee trees in full sun without the incorporation of nutrients; and coffee trees with the incorporation of organic matter from one of the species of Fabaceae-A. mangium, C. cajan, G. sepium and L. leucocephala),

Similarities among the communities of six sampling areas were quantified using Jaccard's index and represented graphically using non-metric multidimensional scaling (n-MDS). An analysis of similarities (ANOSIM) was conducted to test for significant differences in the composition of mite communities. The analyses were conducted using R (R Core Development Team 2014). 


\section{RESULTS AND DISCUSSION}

Across all samples, 1,014 mite specimens of 143 different species were collected. Sarcoptiformes (71 morphospecies and 581 specimens) was the order with the greatest richness and abundance, followed by Mesostigmata (37 morphospecies and 293 specimens), Trombidiformes (28 morphospecies and 128 specimens) and Endeostigmata (7 morphospecies and 12 specimens), as presented in Table 1 and Appendix.

The forest soil had the greatest edaphic mite total abundance and richness (475 specimens and 69 species), while the soil enriched with acacia was the least abundant and rich (27 specimens and 15 species), with the remaining areas having intermediate values (Tables 2 and 3).

As shown in the species discovery curve, which shows the number of species as a function of the number of specimens caught (Fig. 1), the sampling was not sufficient to completely sample the mite community present in the soil of the forestry system, because the asymptote was not achieved. In turn, in the environments with coffee plants, the species discovery curves approach more closely the asymptote, demonstrating that the number of species in these locations is lower than that in

Table 1

List of mite specimens collected in the order of abundance per family and percentage of occurrence in relation to the total.

\begin{tabular}{|c|c|c|c|}
\hline Order & $\begin{array}{r}\text { Abundance } \\
\text { (total specimens) }\end{array}$ & $\%$ & Rate (Abundance/Richness) \\
\hline Sarcoptiformes & 581 & 59.4 & $\begin{array}{l}\text { Astigmatina: Acaridae (135 ind., } 08 \text { ssp.), } \\
\text { Histiostomatidae (23 ind., } 06 \text { ssp.); } \\
\text { Oribatida: Astegistidae (18 ind., } 01 \text { ssp.), } \\
\text { Brachychthoniidae (06 ind., } 02 \text { ssp.), } \\
\text { Camisiidae (01 ind., } 01 \text { ssp.), Ctenacaridae (01 ind., } 01 \text { ssp.), } \\
\text { Cultroribula (02 ind., } 01 \text { ssp.); Damaeidae (16 ind., } 01 \text { ssp.), } \\
\text { Damaeolidae (02 ind., } 01 \text { ssp.), Epilohmannidae (21 ind., } 01 \text { ssp.), } \\
\text { Eremulidae (08 ind., } 03 \text { ssp.), Euphthiracaridae (05 ind., } 02 \text { ssp.), } \\
\text { Galumnidae (11 ind., } 01 \text { ssp.), Haplozetidae (01 ind., } 01 \text { ssp.); } \\
\text { Hypochthoniidae (85 ind., } 02 \text { ssp.), Licnodamaeidae (41 ind., } 01 \text { ssp.) } \\
\text { Lohmaniidae (02 ind., } 02 \text { ssp.), Mesoplophoridae (10 ind., } 03 \text { ssp.), } \\
\text { Microzetidae (01 ind., } 01 \text { ssp.), Nothridae (01 ind., } 01 \text { ssp.), } \\
\text { Oppiidae (19 ind., } 05 \text { ssp.), Oribatellidae (11 ind., } 05 \text { ssp.), } \\
\text { Pheroliodidae (03 ind., } 01 \text { ssp.), Quadropiidae (01 ind., } 01 \text { ssp.); } \\
\text { Scheloribatidae (25 ind., } 01 \text { ssp.), Suctobelbidae (52 ind., } 6 \text { ssp.), } \\
\text { Tectocepheidae (08 ind., } 1 \text { ssp.); youth Oribatida not identified (73) }\end{array}$ \\
\hline Mesostigmata & 293 & 27.2 & 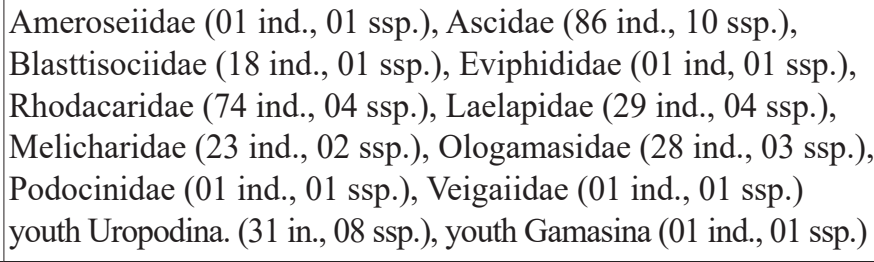 \\
\hline Trombidiformes & 128 & 12.4 & $\begin{array}{l}\text { Cheyletidae (02 ind., } 01 \mathrm{ssp} .) \text {, Cunaxidae (08 ind., } 06 \text { ssp.), } \\
\text { Ereynetidae (02 ind., } 01 \text { ssp.), Erythraeidae (01 ind., } 01 \text { ssp.), } \\
\text { Eupodidae (62 ind., } 02 \text { ssp.), Scutacaridae ( } 36 \text { ind., } 06 \text { ssp.), } \\
\text { Neopygmephoridae (06 ind., } 03 \text { ssp.), Rhagidiidae (06 ind., } 02 \text { ssp.), } \\
\text { Ereynetidae (02 ind., } 01 \text { ssp.), Stigmaeidae (03 ind., } 02 \text { ssp.), } \\
\text { Tydeidae (01 ind., } 01 \text { ssp.), Smaridae (01 ind., } 01 \text { ssp.). }\end{array}$ \\
\hline Endeostigmata & 12 & 1.0 & $\begin{array}{l}\text { Alycidae (09 ind., } 4 \text { ssp.), Alicorhagiidae (02 ind., } 02 \text { ssp.), } \\
\text { Nanorchestidae (01 ind., } 1 \text { ssp.) }\end{array}$ \\
\hline Total & 1,014 & 100.0 & \\
\hline
\end{tabular}

ind.- -abundance of specimens; ssp.- - number of morphospecies. 
natural forest environments, and that the sampling was close to ideal, having sampled almost the entire diversity of the mite communities present in the local soils (Fig. 1).

The abundance of each edaphic mite group varied, and the number of specimens depended on the type of soil and the quantity of organic matter, as well as on other environmental factors, such as moisture content and $\mathrm{pH}$ (Badejo 1990). However, mites are one of the edaphic groups with the largest number of species, both in natural and in cultivated areas (Hijii 1987; Minor and Cianciolo 2007; Mussury et al. 2008; Souto et al. 2008; Lorenzon and Machado Filho 2012). In the present study, as in other similar studies conducted in Brazil, oribatid mite species (Acari: Oribatida), the abundance and richness categories dominated (Badejo 1990; Badejo et al. 2004; Duarte 2004; Morais et al. 2010). In addition, it has been noted that the edaphic arthropod fauna, including mites, can vary with changes to the soil management system, especially when natural systems are replaced by monocultures (Crossley et al. 1992; Minor and Cianciolo 2007). In the present study, significant differences between samplings conducted in the forest and in the coffee cultivation systems were clear (Fig. 2, Tables 2 and 3), with a decrease in the species richness and abundance occurring in the latter environment.

As previously mentioned, the native forest had the greatest abundance of mites in the soil. However, among the coffee plantation treatments, there were no significant differences in edaphic mite abundance between those areas where organic matter was not incorporated, and those where organic matter of C. cajan, G. sepium or L. leucocephala were incorporated. The areas where organic matter of $A$. mangium was incorporated, had

Table 2

Total abundance of edaphic mite specimens, sampled at EPAMIG Sul Experimental Farm, São Sebastião do Paraíso, MG, 2012-2013. Forest-native forest; CPFS - coffee tree plantation in full sun without organic matter; C. cajan (CC), L. leucocephala (LL), G. sepium (GS) and A. mangium (AM) - coffee plantation areas with the incorporation of organic matter from species of Fabaceae.

\begin{tabular}{|l|r|r|r|r|r|r|}
\hline Taxon & Forest & CPFS & CC & LL & GS & AM \\
\hline Oribatida & 301 & 52 & 18 & 25 & 21 & 6 \\
\hline Astigmatina & 4 & 22 & 36 & 59 & 32 & 5 \\
\hline Mesostigmata & 102 & 47 & 52 & 64 & 13 & 15 \\
\hline Trombidiformes & 58 & 9 & 14 & 33 & 13 & 1 \\
\hline Endeostigmata & 10 & 0 & 1 & 0 & 1 & 0 \\
\hline Total & 475 & 130 & 121 & 181 & 80 & 27 \\
\hline
\end{tabular}

Table 3

Total species richness of edaphic mites sampled at EPAMIG Sul Experimental Farm, São Sebastião do Paraíso, MG, 2012-2013. Forest - native forest; CPFS — coffee tree plantation in full sun without organic matter; C. cajan (CC), L. leucocephala (LL), G. sepium (GS) and A. mangium (AM) - coffee plantation areas with the incorporation of organic matter from species of Fabaceae.

\begin{tabular}{|l|r|r|r|r|r|r|}
\hline Taxon & Forest & CPFS & CC & LL & GS & AM \\
\hline Oribatida & 43 & 21 & 11 & 12 & 6 & 3 \\
\hline Astigmatina & 4 & 5 & 5 & 8 & 3 & 2 \\
\hline Mesostigmata & 15 & 13 & 16 & 8 & 8 & 9 \\
\hline Trombidiformes & 7 & 6 & 2 & 3 & 1 & 1 \\
\hline Endeostigmata & 0 & 1 & 0 & 1 & 0 & 0 \\
\hline Total & 69 & 46 & 34 & 32 & 18 & 15 \\
\hline
\end{tabular}


significantly lower abundance than the others (Tables 2 and 3, Fig. 2).

Significant differences were also observed in edaphic mite species richness, with the highest being associated with the native forest environment. Among the treatments, the leucena, L. leucocephala, had the greatest richness, followed by areas where no organic matter was incorporated. The areas where pigeon pea, C. cajans, and gliricidia, G. sepium, were incorporated, did not differ significantly. The areas where acacia, A. mangium, was incorporated, had the lowest species richness and abundance (Tables 2 and 3, Fig. 2).

The edaphic mite group that was most affected by the changes to the crop management system was Oribatida: its richness and abundance decreased even in the areas where organic matter of Fabaceae species was incorporated into the soil (Tables 2 and 3). This group of mites is sensitive to environmental changes. Oribatid mites are an important component of the edaphic fauna, since they play a role in nutrient cycling. Therefore, these mites are essential for maintaining natural cycles of renovation and incorporation of organic matter into the soil (Crossley et al. 1992; Behan-Pelletier 1999; Minor and Cianciolo 2007; Norton and BehanPelletier 2009). The loss of these species can cause an imbalance in natural nutrient cycles. Thus, practices that assure presence of this group of species in cultivated areas are important for maintaining soil quality. Although the practice of incorporating organic matter into the soil is important for maintaining nutritional and physical properties of the soil (Ricci 2005), it is not sufficient for preserving the mite community. It was initially hypothesized that places where organic matter was incorporated into the soil, would have greater abundances of soil mites, and that their abundance and richness would be similar to those found in the natural forest. This, however, turned out not to be the case. Further research is needed to better understand how this practice may be implemented more efficiently in order to better maintain population sizes of mites in the soils of cultivated systems.

The hypothesis (which may explain the results of the present study) that the quantity and quality of the vegetable matter deposited under the coffee trees, is not adequate. A greater amount and diversity of vegetable substrates may be necessary. Determining the ideal amount and type of vegetable matter may be the topic of future research. However, there is evidence that changes in soil management practices, and an adequate incorporation of organic matter may significantly increase the abundance of oribatids and other edaphic mites (Khalil et al. 2016). In addition, it is known that

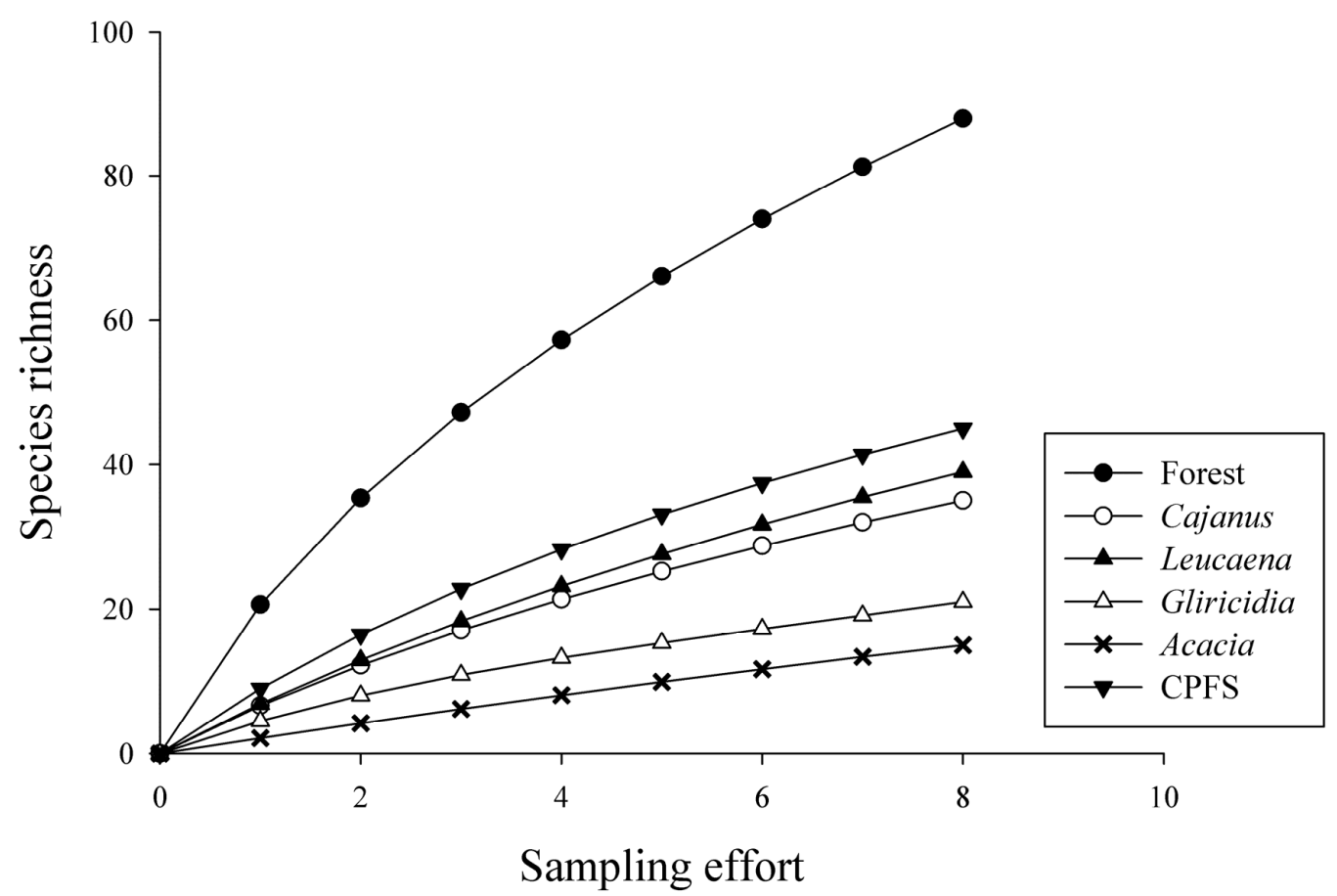

Fig. 1. Species accumulation curves for the soil mite communities, sampled at EPAMIG Sul Experimental Farm, São Sebastião do Paraíso, MG, 2012-2013. Forest—native forest; CPFS - coffee tree plantation in full sun without organic matter; C. cajan, L. leucocephala, G. sepium and A. mangium — coffee plantation areas with the incorporation of organic matter from species of Fabaceae. 
the leaves of acacia, A. mangium, contain the chemical compounds, such as tannin (Correa 1984), which is potentially harmful to mite communities. Such compounds may reduce the populations of mite species (Fernández-Salas et al. 2011). Therefore, choosing the most appropriate plant species to be used in soil management practices must be an initial step towards preserving the mite community.

The practice of converting natural ecosystems into agricultural ones usually decreases microarthropod population in the soil. In addition, removing native vegetation may negatively affect the species richness and abundance of edaphic mite communities (Edwards and Lofty 1975; Wallwork 1976; Blevins et al. 1984; Minor and Cianciolo
2007). Such negative effects are also a result of drastic changes in microclimatic conditions, such as humidity and temperature, chemical changes, and the destruction of microhabitats (Crossley et al. 1981; Blevins et al. 1984; Perdue 1992). In addition to changes in species richness and abundance, alterations to the crop management system can lead to a complete change in the soil mite community with the substitution of species. All of the studied treatment environments possessed a low degree of similarity with the native forest. More specifically, the treated and forest environments frequently shared less than $18 \%$ of their species, which shows that different soil management practices strongly affect edaphic mite communities (Table 4).
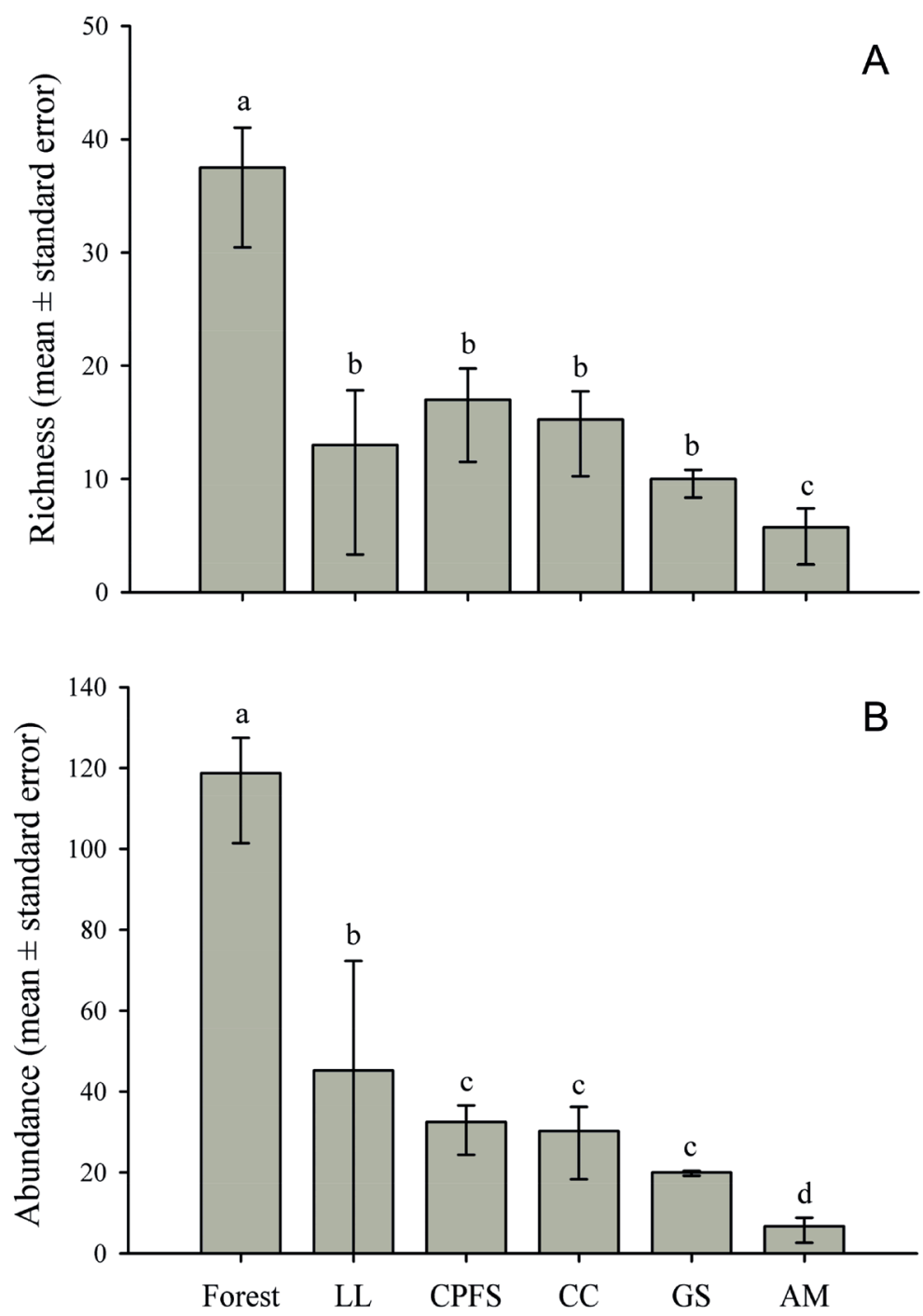

Fig. 2. Comparison of means (GLM) for total species richness (A) and total abundance (B) of mites found in the studied systems at EPAMIG Sul Experimental Farm, São Sebastião do Paraíso, MG, 2012. Different letters indicate significant differences between means $(\mathrm{p}<0.05)$. Forest - native forest; CPFS - coffee tree plantation in full sun without organic matter; Cajanus cajan (CC), Leucena leucocephala (LL), Gliricidia sepium (GS) and Acacia mangium (AM) - coffee plantation areas with the incorporation of organic matter. 
As shown in Fig. 3 and Table 5, the composition of the forest system mite community is significantly different from that of the cultivated systems; whether they are managed with the Fabaceae organic matter or not.

The substitution of native forests with cultivated systems may cause significant changes in the edaphic mite species richness, abundance and community structure. Nevertheless, the improvements in soil management techniques and agricultural production procedures may revert these impacts, as it can be observed in organic production systems (Khalil et al. 2016).

Biological indicators of soil quality are often used to understand complex environmental changes because they are easily measured, responsive to a wide range of stresses, and they can be employed rather quickly (Pulleman et al. 2012). Mites have a high potential of serving as biological indicators of soil quality (Gulvik 2007). Among the mite groups observed in the present study, oribatid mites exhibited the most evident variation. They responded with a strong reduction in species richness and abundance, especially in comparison of the natural forest with the cultivated systems. According to Gulvik (2007), using oribatids as indicators of soil quality is efficient because a large number of these species possess long lifespans, low fertility rates, lengthy development and low mobility. Therefore, changes in the environment, especially those caused by human activities, are likely to reduce the presence of Oribatida in the environment. It should be mentioned that species identification in tropical environments is often impossible because there are few qualified professionals with the necessary expertise. Nonetheless, oribatids can still be useful in comparing the parameters of richness and abundance among ecosystems with different levels of degradation.

Table 4

Similarities (Jaccard) among the sampled edaphic mite communities. Forest - native forest; CPFS — coffee tree plantation in full sun and without organic matter; C. cajan (CC), L. leucocephala (LL), G. sepium (GS) and A. mangium (AM) - coffee plantation areas with the incorporation of organic matter from the corresponding species of Fabaceae plants.

\begin{tabular}{|l|r|r|r|r|r|}
\hline Environments & Forest & CPFS & CC & LL & GS \\
\hline Forest & - & - & - & - & - \\
\hline CPFS & 17.83 & - & - & - & - \\
\hline CC & 15.87 & 19.82 & - & - & - \\
\hline LL & 12.23 & 16.07 & 23.05 & - & - \\
\hline GS & 12.74 & 17.74 & 18.65 & 26.25 & 31.2 \\
\hline AM & 7.51 & 21.26 & 20.87 & 19.94 & - \\
\hline
\end{tabular}

Table 5

ANOSIM results, comparing mite communities found in the studied native forest and coffee crop systems. Forest - native forest; CPFS - the system without the incorporation of organic matter; $C$. cajan (CC), L. leucocephala (LL), G. sepium (GS) and A. mangium (AM) - systems with the incorporation of organic matter of the corresponding Fabaceae species into the soil.

\begin{tabular}{|l|r|r|}
\hline Environments & T & P (perm) \\
\hline CPFS vs forest & 1.8014 & 0.0299 \\
\hline CC vs forest & 2.6161 & 0.0271 \\
\hline LL vs forest & 1.8065 & 0.0296 \\
\hline GS vs forest & 3.0390 & 0.0284 \\
\hline AM vs forest & 2.4764 & 0.0300 \\
\hline
\end{tabular}




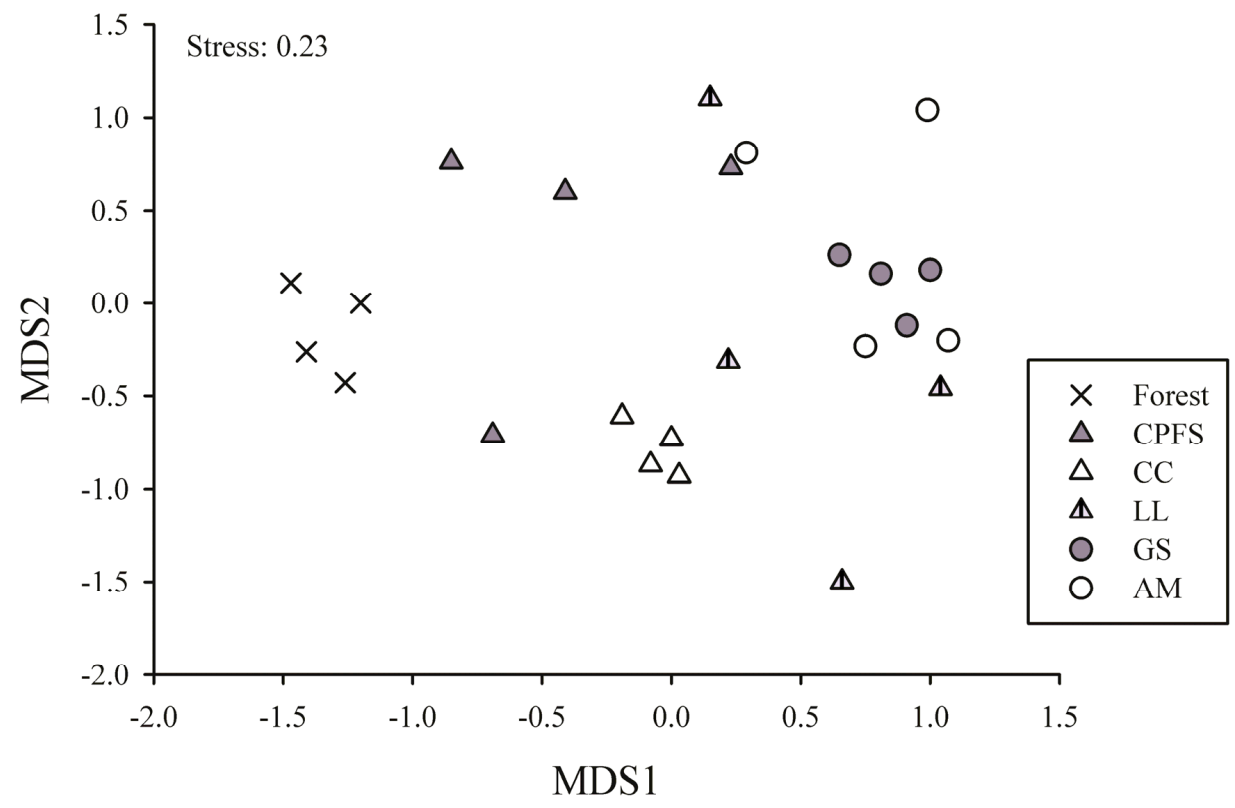

Fig. 3. Multivariate ordination (non-metric multidimensional scaling-NMDS) comparing mite species composition among the studied systems at EPAMIG Sul Experimental Farm, São Sebastião do Paraíso, MG, 2012. Forest-native forest; CPFS - coffee tree plantation in full sun without organic matter; Cajanus cajan (CC), Leucena leucocephala (LL), Gliricidia sepium (GS) and Acacia mangium (AM) _ coffee plantation areas with the incorporation of organic matter.

\section{CONCLUSION}

The edaphic mite community in general, and oribatid mites in particular, were found to respond to the replacement of forest by cultivated plantations, as well as to the incorporation of material of different species of Fabaceae plants into the soil in the areas of coffee tree cultivation. The degrees of mite communities' responses were established by measuring the changes in their richness and abundance. Oribatida was one of the most relevant taxa in the present study, since it was widely distributed (i.e. it had the highest richness and abundance) among the studied environments, including the natural forest and areas of soil management practices. The response of orbatids to environmental alterations is expressive, and, according to our results, they can be used as effective biological indicators.

Since the incorporation of organic matter into the soil may minimize the negative effects of cropping, it should be considered as a viable soil management technique.

\section{ACKNOWLEDGEMENTS}

For financial support and scholarships, we thank the Federal University of Lavras (UFLA), the Agricultural Research Company of Minas Gerais (EPAMIG Sul/EcoCentro), the Coordination of Improvement of Higher Level Personnel (CAPES) and the National Council for Scientific and Tech- nological Development (CNPq). We thank the following taxonomic specialists for their help with the identification of some mite groups: Pavel Klimov (Astigmatina), Matheus Rocha (Cunaxidae) and Rafael Castilho (Ascoidea and Rhodacaroidea). We thank Livia Dorneles Audino for assistance with the statistical analyses. Lastly, we thank the editor and the anonymous reviewers for their helpful comments on the manuscript.

\section{REFERENCES}

Badejo, M.A. 1990. Seasonal abundance of soil mites (Acarina) in two contrasting environments. Biotropica, 22: 382-390.

Badejo, M.A., Aquino, A.M., De-Polli, H. and Fernandes Correia, M.E. 2004. Response of soil mites to organic cultivation in an ultisol in southeast Brazil. Experimental and Applied Acarology, 34: 345-365.

Bedano, J.C., Cantú, M.P. and Doucet, M.E. 2006. Influence of three different land management practices on soil mite (Arachnida: Acari) densities in relation to a natural soil. Applied Soil Ecology, 32: 293-304.

Bedano, J.C. and Ruf, A. 2010. Sensitivity of different taxonomic levels of soil Gamasina to land use and anthropogenic disturbances. Agricultural and Forest Entomology, 12: 203-212.

Behan-Pelletier, V.M. 1999. Oribatid mite biodiversity in agroecosystems: role for bioindication. 
T.A.F. Carvalho, P.R. Reis, L.F.O. Bernardi et al.

Agriculture, Ecosystems and Environment, 74: 411-423.

Camargo, A.J.A., Oliveira, C.M., Frizzas, M.R., Sonoda, K.C. and Corrêa, D.C.V. 2015. Coleções entomológicas: Legislação brasileira, coleta, curadoria e taxonomia para as principais ordens. In: A.J.A. Camargo, C.M. Oliveira, M.R. Frizzas, K.C. Sonoda and D.C.V. Corrêa (Eds.). Embrapa Cerrados, Brasília/Fortaleza.

Castilho, R.C., Moraes, G.J., Silva, E.S. and Silva, L.O. 2009. Predation potential and biology of Protogamasellopsis posnaniensis Wisniewski and Hirschmann (Acari: Rhodacaridae). Biological Control, 48: 164-167.

Crossley, D.A., Mueller, B.R. and Perdue, J.C. 1992. Biodiversity of microarthropods in agricultural soils: relations to processes. Agriculture, Ecosystems and Environment, 40: 37-46.

Duarte, M.M. 2004. Abundância de microartrópodes do solo em fragmentos de mata com araucária no sul do Brasil. Iheringia, Série Zoologia, 94: 163-169.

Evans, D. and Campbell, N.J.H. 2003. Exotic vs endemic biocontrol agents: would the real Stratiolaelaps miles (Berlese) (Acari: Mesostigmata: Laelapidae), please stand up? Biological Control, 26: 253-269.

Hijii, N. et al.1987. Seasonal changes in abundance and spatial distribution of the soil arthropods in a Japanese cedar (Cryptomeria japonica D. Don) plantation, with special reference to Collembola and Acarina. Ecological Research, 159-173.

Hülsmann, A. and Wolters, V. 1998. The effects of different tillage practices on soil mites, with particular reference to Oribatida. Applied Soil Ecology, 9: 327-332.

Krantz, G.W. and Walter, D.E. (Eds.). 2009. I Manual of Acarology. Third edition. Texas Tech University Press, Lubbock, Texas.

Lindquist, E.E., Krantz, G.W. and Walter, D.E. 2009. Classification. In: G.W. Krantz and D.E. Walter (Eds.). A Manual of Acarology. Texas Tech University Press, Lubbock, Texas, p. 97.

Marafeli, P.D.P., Reis, P.R., Bernardi, L.F.O. and Martinez, P.A. 2018. Faunistic analysis of soil mites in coffee plantation. International Journal of Environmental and Agriculture Research, 4: 42-58.

Moguel, P. and Toledo, V.M. 1999. Review: Biodiversity conservation in traditional coffee systems of Mexico. Conservation Biology, 13: 11-21.

Morais, J.W., Oliveira, V.S., Dambros, C.S., TapiaCoral, S.C. and Acioli, A.N.S. 2010. Soil mesofauna in differents systems of land use soil in
Upper River Solimões, AM, Brazil. Neotropical Entomology, 39: 145-152.

Moreira, G.F., Morais, M.R., Busoli,A.C. and Moraes, G.J. 2015. Life cycle of Cosmolaelaps jaboticabalensis (Acari: Mesostigmata: Laelapidae) on Frankliniella occidentalis (Thysanoptera: Thripidae) and two factitious food sources. Experimental and Applied Acarology, 65: 219-226.

Oliveira, C.M., Resck, V.D.S. and Frizzas, M.R. 2006. Artrópodes edáficos: influência dos sistemas de preparo do solo e de rotação de culturas. Embrapa Cerrados, Planaltina.

Pepato, A.R. and Klimov, P.B. 2015, Origin and higher-level diversification of acariform mitesevidence from nuclear ribosomal genes, extensive taxon sampling, and secondary structure alignment. BMC Evolutionary Biology, 15: 178-198.

Perfecto, I., Rice, R.A., Greenberg, R. and Voort, M.E 1996. Shade coffee: a disappea refuge for biodiversity. BioScience, 46: 598-608.

R Core Development Team. 2014. A language and environment for statistical computing. R Foundation for Statistical Computing, Vienna. www.rproject.org.

Rojas, A.B., Castaño-Meneses, G., Palacios-Vargas, J.G. and García-Calderón, N.E. 2009. Oribatid mites and springtails from a coffee plantation in Sierra Sur, Oaxaca, Mexico. Pesquisa Agropecuária Brasileira, 44: 988-995.

Ruf, A. 1998. A maturity index for predatory soil mites (Mesostigmata: Gamasina) as an indicator of environmental impacts of pollution on forest soils. Applied Soil Ecology, 9: 447-452.

Ruf, A. and Beck, L. 2005. The use of predatory soil mites in ecological soil classification and assessment concepts, with perspectives for oribatid mites. Ecotoxicology and Environmental Safety, 62: 290-299.

Souto, P.C., Souto, J.S., Miranda, J.R.P., Santos, R.V. and Alves, A.R. 2008. Comunidade microbiana e mesofauna edáficas em solo sob caatinga no semiárido da Paraíba. Revista Brasileira de Ciencia do Solo, 32: 151-160.

Wallace, M.M.H., Tyndale-Bidcoe, M. and Holm, E. 1979. The influence of Macrocheles glaber on the breeding of the Australian bush fly, Musca vetustissima, in cow dung. In: J.G. Rodriguez (Ed.). Recent Advances in Acarology, Vol II. Academic Press, London, pp. 217-222.

Walter, D.E. and Krantz, G.W. 2009. Collection, rearing, and preparing specimens. In: G.W. Krantz and D.E. Walter (Eds.) Manual of Acarology. Texas Tech University Press, Lubbock, Texas, pp. 83-96. 
Appendix

Taxonomic groups that were identified in each of the systems studied. Forest - native forest; CPFS - coffee plantation in full sun, with the absence of organic matter; Cajanus cajan (CC), Leucena leucocephala (LL), Gliricidia sepium (GS) and Acacia mangium (AM)coffee plantation areas with the incorporation of organic matter.

\begin{tabular}{|c|c|c|c|c|c|c|c|c|}
\hline Order & Taxa & Genus/Species & Forest & CPFS & $\mathrm{CC}$ & $\mathbf{L L}$ & GS & AM \\
\hline \multirow[t]{4}{*}{ Endeostigmata } & Alicorhagiidae & * & $\mathrm{X}$ & & & & & \\
\hline & Alycidae & Alycus ssp. & & & $\mathrm{X}$ & & & \\
\hline & Alycidae & Bimichaelia ssp. & $\mathrm{X}$ & & & & & \\
\hline & Nanorchestidae & Nanorchestes ssp. & & & & & $\mathrm{X}$ & \\
\hline \multirow[t]{19}{*}{ Mesostigmata } & Ameroseiidae & Ameroseius ssp. & $\mathrm{X}$ & & & & & \\
\hline & Ascidae & $*$ & $\mathrm{X}$ & & & & & \\
\hline & Ascidae & Asca ssp. & $\mathrm{X}$ & & & $\mathrm{X}$ & & \\
\hline & Ascidae & Protogamasellus sigillophorus & $\mathrm{X}$ & $\mathrm{X}$ & $\mathrm{X}$ & & $\mathrm{X}$ & \\
\hline & Blattisociidae & Lasioseius ssp. & $\mathrm{X}$ & & $\mathrm{X}$ & $\mathrm{X}$ & & \\
\hline & Eviphididae & * & & & $\mathrm{X}$ & & & \\
\hline & Laelapidae & Cosmolaelaps ssp. & $\mathrm{X}$ & $\mathrm{X}$ & $\mathrm{X}$ & & & $\mathrm{X}$ \\
\hline & Laelapidae & Gaeolaelaps ssp. & & & $\mathrm{X}$ & & & \\
\hline & Laelapidae & Pseudoparasitus ssp. & $\mathrm{X}$ & & & & & \\
\hline & Melicharidae & Proctolaelaps paulista & & $\mathrm{X}$ & & $\mathrm{X}$ & & \\
\hline & Melicharidae & Proctolaelaps ssp. & & & & & & $\mathrm{X}$ \\
\hline & Ologamasidae & Gamasiphis ssp. & $\mathrm{X}$ & & & $\mathrm{X}$ & $\mathrm{X}$ & $\mathrm{X}$ \\
\hline & Ologamasidae & Neogamasellevans ssp. & $\mathrm{X}$ & & $\mathrm{X}$ & & $\mathrm{X}$ & \\
\hline & Podocinae & Podocinum ssp. & $\mathrm{X}$ & & & & & \\
\hline & Rhodacaridae & Multidentor hodacarus & $\mathrm{X}$ & $\mathrm{X}$ & $\mathrm{X}$ & $\mathrm{X}$ & & $\mathrm{X}$ \\
\hline & Rhodacaridae & Protogamasellopsis ssp. & & $\mathrm{X}$ & & $\mathrm{X}$ & & $\mathrm{X}$ \\
\hline & Rhodacaridae & Rhodacarellus ssp. & & $\mathrm{X}$ & & $\mathrm{X}$ & & $\mathrm{X}$ \\
\hline & Uropodina & * & $\mathrm{X}$ & & & $\mathrm{X}$ & $\mathrm{X}$ & $\mathrm{X}$ \\
\hline & Veigaiidae & * & & & & $\mathrm{X}$ & & \\
\hline \multirow[t]{10}{*}{ Sarcoptiformes } & Acaridae & * & & $\mathrm{X}$ & $\mathrm{X}$ & $\mathrm{X}$ & & \\
\hline & Acaridae & Tyrophagus ssp. & $\mathrm{X}$ & $\mathrm{X}$ & $\mathrm{X}$ & $\mathrm{X}$ & $\mathrm{X}$ & $\mathrm{X}$ \\
\hline & Histiostomatidae & $*$ & $\mathrm{X}$ & & & & & \\
\hline & Astegistidae & Cultroribula ssp. & $\mathrm{X}$ & $\mathrm{X}$ & & $\mathrm{X}$ & & \\
\hline & Brachichthoniidae & * & $\mathrm{X}$ & & & & & \\
\hline & Brachychthoniidae & Liochthonius aff. fimbriatissimus & & & & $\mathrm{X}$ & & \\
\hline & Camisiidae & Camisia ssp. & $\mathrm{X}$ & & & & & \\
\hline & Ctenacaridae & $*$ & $\mathrm{X}$ & & & & & \\
\hline & Cultroribula & Cultroribula ssp. & & & & & $\mathrm{X}$ & \\
\hline & Damaeidae & $*$ & $\mathrm{X}$ & & & & & \\
\hline
\end{tabular}


T.A.F. Carvalho, P.R. Reis, L.F.O. Bernardi et al.

\begin{tabular}{|c|c|c|c|c|c|c|c|c|}
\hline & Damaeolidae & Fosseremus ssp. & & $\mathrm{X}$ & & & & \\
\hline & Epilohmannidae & Epilohmannia pallida americana & $\mathrm{X}$ & $\mathrm{X}$ & $\mathrm{X}$ & $\mathrm{X}$ & & \\
\hline & Eremulidae & Eremulus ssp. & $\mathrm{X}$ & $\mathrm{X}$ & & & & \\
\hline & Eremulidae & Eremulus crisspus & $\mathrm{X}$ & & & & & \\
\hline & Euphthiricaridae & $*$ & $\mathrm{X}$ & & & & & \\
\hline & Galumnidae & Galumna ssp. & $\mathrm{X}$ & $\mathrm{X}$ & & $\mathrm{X}$ & & \\
\hline & Haplozetidae & Rostrozetes ssp. & $\mathrm{X}$ & & & & & \\
\hline & Hypochthoniidae & Eohypochthonius ssp. & $\mathrm{X}$ & & & & & \\
\hline & Hypochthoniidae & Malacoangelia ssp. & $\mathrm{X}$ & & & & & \\
\hline & Licnodamaeidae & $*$ & $\mathrm{X}$ & $\mathrm{X}$ & & & & \\
\hline & Lohmanniidae & Lohmannia ssp. & $\mathrm{X}$ & & & & & \\
\hline & Lohmanniidae & Papillacarus ssp. & & $\mathrm{X}$ & & & & \\
\hline & Mesoplophoridae & * & $\mathrm{X}$ & & & & & \\
\hline & Mesoplophoridae & Mesoplophora ssp. & $\mathrm{X}$ & & & & $\mathrm{X}$ & \\
\hline & Microzetidae & Berlesezetes ssp. & & $\mathrm{X}$ & & & & \\
\hline & Nothridae & Nothrus ssp. & $\mathrm{X}$ & & & & & \\
\hline & Oppiidae & Microppia ssp. & $\mathrm{X}$ & & & & & \\
\hline & Oppiidae & Lanceoppia ssp. & $\mathrm{X}$ & $\mathrm{X}$ & & & & \\
\hline & Oppiidae & Ramusella ssp. & $\mathrm{X}$ & & & & & \\
\hline & Oppiidae & Striatoppia ssp. & $\mathrm{X}$ & $\mathrm{X}$ & $\mathrm{X}$ & & & \\
\hline & Oribatellidae & Lamellobates botari & $\mathrm{X}$ & $\mathrm{X}$ & $\mathrm{X}$ & $\mathrm{X}$ & & $\mathrm{X}$ \\
\hline & Pheroliodidae & Pheroliodes ssp. & $\mathrm{X}$ & & & & & \\
\hline & Quadroppiidae & Quadroppia ssp. & $\mathrm{X}$ & & & & & \\
\hline & Scheloribatidae & Scheloribates praencisus acuticlava & $\mathrm{X}$ & $\mathrm{X}$ & $\mathrm{X}$ & & $\mathrm{X}$ & $\mathrm{X}$ \\
\hline & Suctobelbidae & $*$ & $\mathrm{X}$ & & & $\mathrm{X}$ & & \\
\hline & Suctobelbidae & Suctobelbella ssp. & $\mathrm{X}$ & $\mathrm{X}$ & $\mathrm{X}$ & $\mathrm{X}$ & & \\
\hline & Suctobelbidae & Suctobelbella aff. ornatissima & & & & $\mathrm{X}$ & & \\
\hline & Suctobelbidae & Suctobelbella variosetosa & $\mathrm{X}$ & $\mathrm{X}$ & $\mathrm{X}$ & $\mathrm{X}$ & & \\
\hline & Suctobelbidae & Suctobelbella elegantula & $\mathrm{X}$ & $\mathrm{X}$ & $\mathrm{X}$ & $\mathrm{X}$ & & \\
\hline & Suctobelbidae & Suctobelbella aff. loksai & $\mathrm{X}$ & $\mathrm{X}$ & $\mathrm{X}$ & $\mathrm{X}$ & & \\
\hline & Suctobelbidae & Cultroribula cf. zicsii & $\mathrm{X}$ & $\mathrm{X}$ & $\mathrm{X}$ & $\mathrm{X}$ & & \\
\hline & Tectocepheidae & Tectocepheus velatus & $\mathrm{X}$ & $\mathrm{X}$ & $\mathrm{X}$ & & $\mathrm{X}$ & \\
\hline \multirow[t]{6}{*}{ Trombidiformes } & Cheyletidae & $*$ & & & & & $\mathrm{X}$ & \\
\hline & Cunaxidae & Neocunaxides ssp. & $\mathrm{X}$ & $\mathrm{X}$ & & & & \\
\hline & Cunaxidae & Cunaxa ssp. & $\mathrm{X}$ & & $\mathrm{X}$ & & & \\
\hline & Cunaxidae & Coleoscirus ssp. & & $\mathrm{X}$ & & & & \\
\hline & Cunaxidae & Dactyloscirus ssp. & & $\mathrm{X}$ & & & & \\
\hline & Cunaxidae & Parabonzia ssp. & & & $\mathrm{X}$ & & & \\
\hline
\end{tabular}


Edaphic mites and their reponse to organic matter

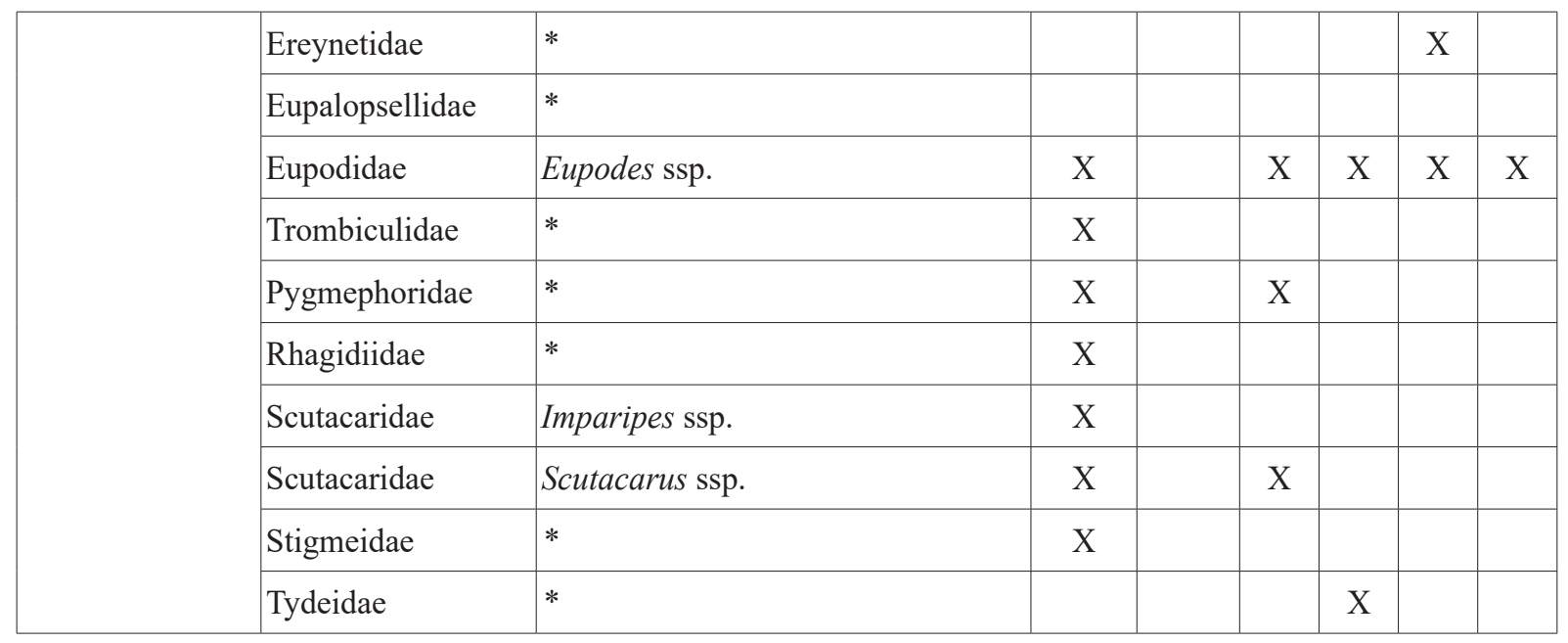

*_unidentified species. 